ISSN 1676-3742

\title{
Evágrio Pôntico: introdução à vida, obra e teologia espiritual
}

Teresa Messias

\section{Resumo}

Este artigo estuda a biografia de Evágrio Pôntico, noções fundamentais e influências do seu ensino espiritual: a noção de criação, a antropologia teológica e sua doutrina ascético-mística. $\mathrm{O}$ artigo salienta a especificidade da noção evagriana de apátheia e a sua relevância na teologia ascética-mística do autor.

Palavras-chave: Evágrio Pôntico, Espiritualidade, Padres do Deserto, Teologia Mística.

\section{Abstract}

This article studies Evagrius Ponticus biography, fundamental notions and the grass roots of his spiritual teachings: the notion of creation, his theological anthropology and ascetical-mystical doctrine. The article emphasizes the specificity of the Evagrian notion of apátheia and its relevance in the author's ascetical-mystical theology. 
Keywords: Evagrius Ponticus, Spirituality, Desert Fathers, Mystical Theology.

\section{Introdução}

Evágrio Pôntico insere-se no importante movimento espiritual que surgiu na Igreja no século III, cuja origem é, ainda hoje, difícil de traçar, produzido em áreas desérticas do Egipto e da Síria, constituindo a base primitiva de um novo estilo de vida cristã: o monacato. Dentro deste movimento, marcado pelo abandono da vida social das cidades, de uma busca incessante da união com Deus na solidão orante, na quietude contemplativa e no trabalho manual, destacaram-se algumas figuras de singular percurso ascético-místico reconhecidas no seu tempo como mestres espirituais: os Padres do Deserto. Contribuiram com a sua experiência, entre outros aspectos, para o desenvolvimento da Teología Mística (doutrina ou teologia da theósis) e da arte do discernimento dos espíritos (diakrísis). O autor estudado, discípulo de Gregório de Nazianzo e de Basílio de Cesareia, muito influenciado pelo pensamento de Orígenes, deixou influências profundas, do Oriente ao Ocidente, através do influxo que exerceu sobre outros autores que adoptaram vários elementos da sua doutrina e as suas categorias. Ainda hoje a Teologia Espiritual sofre influência decisiva, mas nem sempre consciente, da doutrina evagriana e da sua noção de itinerário espiritual e discernimento, mesmo depois da condenação das teses origenistas presentes no seu pensamento pelo II Concílio de Constantinopla (553), através das obras do Pseudo-Dioníso Areopagita, de Máximo, o Confessor, ou de João Cassiano, para citar alguns dos que foram influenciados pela doutrina mística de Evágrio e a transmitiram.

Este artigo tem por objectivo apresentar concisamente a doutrina ascético-mística do autor, as suas fases e os marcadores mais importantes que assinalam a transformação pessoal sofrida - dando particular destaque para a noção de apátheia - até à fase da união com Deus ou divinização do orante. Com esse fim faz uma análise de fontes selecionadas do seu pensamento que desenvolve através da seguinte estrutura: 1) resumo biográfico, 2) indicação da obra produzida e discussão sobre o acesso às fontes, 3) principais influências filosóficas e teológicas, 4) antropologia teológica subjacente, 5) doutrina ascético-mística, 6) A theologia como oração ou contemplação pura. 


\section{A vida de Evágrio Pôntico}

Evágrio nasce por volta de 345 , em Ibora, filho de um episcopo ${ }^{1}$ na então província romana do Ponto $^{2}$ (anexada ao império em 66 a.C mas que no sec. I incluída também o território da Bitínia), situada ao norte da Ásia Menor, hoje Turjak, província de Tokat, na Turquia. Muito perto desta cidade ficava Annésoi, propriedade da família de São Basílio de Cesareia, local para onde este último se foi retirar em 357-358, acompanhado de S. Gregório de Nazianzo, com o fim de ambos viverem aí um estilo de vida monástico. Graças a esta proximidade Evágrio toma contacto com estes dois Padres cujas vidas e obras deixaram marca no período da Igreja Antiga. Sob a sua orientação, começa o seu percurso formativo para se vir a tornar um ministro ordenado na Igreja.

Chega a receber o leitorado das mãos de S. Basílio mas a morte deste, em 379, fará com que seja S. Gregório de Nazianzo quem continuará a ser o seu mestre e orientador e o ordenará diácono. Por isso é sobretudo S. Gregório de Nazianzo que Evágrio refere como mestre, dizendo que ele "o plantou". ${ }^{3}$ Sabe-se que Gregório levou Evágrio para Constantinopla (380) e o instruiu na Filosofia e nas Ciências Sagradas ${ }^{4}$. Aí permanece quando Gregório Nazianzo renuncia ao cargo de Bispo e deixa a Sé Patriarcal da cidade, em 381, ficando com o seu sucessor, o Bispo Nectário, junto do qual deu provas

\footnotetext{
${ }^{1}$ Bispos auxiliares dos Bispos titulares das cidades episcopais na administração de grupos de cristãos que viviam no campo, no interior das províncias episcopais, e cujo ministério implicava (desde muito cedo) uma restrição de poderes em relação ao dos Bispos titulares.

${ }^{2}$ Segundo refere A. Guillaumont, o pouco que se sabe sobre a vida de Evágrio provém do capítulo trinta e oito que lhe dedicou o seu discípulo Palladio, na obra que compôs com o título História Lausíaca, cerca do ano 420, ou seja cerca de vinte anos depois da morte do seu mestre. Cf. A. Guillaumont, "Étude historique et doctrinale", in Évagre le Pontique, Traité Pratique ou Le Moine, Tome I (Sources Chrétiennes 170), Cerf, Paris 1971, 21. Daqui em diante esta obra será referida com a abreviatura Traité Pratique I. Cf. C. Butlen, The Lausiac History of Palladius, t.2, coll. Texts and Studies, Cambridge 1904, 116-123. Versão italiana: Palladio, La storia lausiaca (Introduzione di Christine Mohrmann, testo critico e commento a cura di G. J. M. Bartelink; traduzione di Marino Barchiesi), Fondazione Lorenzo Valla - A. Mondatori, Milano $1990^{4}$.

${ }^{3}$ Épilogo do Tratado Prático em Évagre le Pontique, Traité Pratique ou Le Moine, Tome II, (Sources Chrétiennes 171), Cerf, Paris 1971, 713. Daqui em diante esta obra será referida com a abreviatura Traité Pratique II.

${ }^{4}$ Segundo Sozomeno, historiador do sec. V. Cf. Hermias Sozomenus, Historia Ecclesiastica, in MIGNE, J.-P. (Ed.), Patrologiae Cursus Completus, Series Graeca, Brepols, Turnhoult 1970-, Vol. 67, 1384c. Daqui em diante a obra será referida por PG.
} 
de cultura, sabedoria e uma particular capacidade para capacidade dialéctica para argumentar contra as heresias e controvérsias que surgiam. ${ }^{5}$

Por esta altura acontece um episódio romanesco ${ }^{6}$ na sua vida que marcará decisivamente o seu futuro. Apaixona-se pela esposa de um alto funcionário (a qual responde à sua paixão ${ }^{7}$ ) e, avisado num sonho dos perigos que corria, deixa a cidade logo na manhã seguinte e embarca para Jerusalém.

Na cidade santa dos judeus é recebido por Melânia, a Anciã (viúva originária de Roma) e Rufino que tinham fundado no Monte das Oliveiras um mosteiro onde albergavam estrangeiros de passagem. Evágrio fica com eles alguns meses (não se sabe o tempo exato) e acaba por esquecer os bons propósitos de conversão feitos em Constantinopla. É Melânia quem, diante de uma doença subitamente advinda, o convence que deve fazer-se monge e ir viver para o deserto do Egipto. ${ }^{8}$

Ao redor de 383 Evágrio chega ao deserto do baixo Egipto. Fica primeiro dois anos na zona de Nítria (hoje Wadi El Natrun - Vale do Natrão ${ }^{9}$ - um dos centros monásticos mais conhecidos do Egipto), ao sul de Alexandria, e mais tarde retira-se para o que era propriamente considerado o "deserto", isto é, a zona das Kellia (Ke/llia) - "as Células" ou "Celas" - dezoito quilómetros a sul de Nítria, onde ficará catorze anos, até à sua morte em 399. As Células constituíam um centro monástico onde os monges levavam vida semi-anacorética, habitando celas individuais que ficavam a uma distância tal umas das outras que os monges não podiam, segundo Rufino, nem ver-se nem compreender-se. ${ }^{10}$

\footnotetext{
${ }^{5}$ Cf. Antoine et Claire Guillaumont, "Évagre le Pontique", Dictionnaire de Spiritualité Ascétique et Mystique, Tome IV-1 ${ }^{\text {ere }}$, Beauschesne, Paris 1960, 1732. Daqui em diante citaremos esta obra com a abreviatura $D S p$. Naquela época as controvérsias doutrinais não eram poucas. Recordemos que o Concílio de Nicéia em 325 tratou de dirimir várias disputas cristológicas (sobretudo o arianismo) relativas à união hipostática, ou seja a união na Pessoa de Jesus, da natureza divina e da natureza humana. O Concílio Ecuménico de Constantinopla em 381 voltou a debater e a condenar outras expressões de arianismo. Por esta altura era Evágrio diácono e auxiliar do Bispo de Constantinopla pelo que é razoável supor que tenha participado de perto em grande parte destas discussões.

${ }^{6} \mathrm{O}$ episódio é relatado de modo pouco claro por Palladio, a quem Evágrio confidenciou este acontecimento. Cf. A. Guillaumont, "Étude historique et doctrinale", in Traité Pratique I, 24.

${ }^{7}$ Ibidem.

${ }^{8}$ Ibidem

${ }^{9} \mathrm{O}$ natrão é um mineral, composto por carbonato de cálcio, bicarbonato de sódio, sal e sulfato de sódio que entrava na composição da fórmula química usada para a mumificação de cadáveres no Egipto e que era especialmente abundante neste vale. Tinha também outros usos no Egipto antigo, especialmente enquanto produto de limpeza: branqueador da roupa e, misturado com argila e óleo, como sabão.

${ }^{10}$ Historia monachorum in Aegypto, 22 PL 21 (1878), 444 C, cit in A. Guillaumont, "Étude historique et doctrinale", in Traité Pratique I, 25.
} 
Como membro das "Células", Evágrio conheceu o célebre Abade Macário, o Alexandrino ( $† 395)$, e o outro Macário, o Egípcio (†389-390), iniciador da vida monástica no deserto de Sketis, também na zona de Wadi El Natrun mas distante das Células a um dia inteiro de marcha. Através da leitura das obras cuja autoria lhe é atribuída com certeza é possível verificar os muitos contactos que Evágrio teve com figuras de relevo e prestígio entre os grandes orantes da Igreja do século IV durante a sua vida nas Células. ${ }^{11}$ Assim, além da formação filosófica e teológica que adquiriu no Ponto e em Constantinopla, com os Padres Capadócios, pôde também receber no deserto do Egipto uma sabedoria prática, empírica e orante, recolhida dos testemunhos e confidências dos Padres do Deserto, sabedoria que se transmitia sobretudo de discípulo a mestre ou de irmão a irmão, como forma de ajuda mútua. Nas Células, Evágrio veio a tornar-se Mestre ou chefe de um grupo de monges a que o seu discípulo Palladio chamou o "grupo de Santo Ammónios e de Evágrio". ${ }^{12}$

O perfil intelectual de Evágrio deve ter sido fora de comum para o ambiente das Células, do qual se sabe que os monges aí residentes eram, na sua maioria, camponeses egípcios iletrados, não falando senão Copta. ${ }^{13} \mathrm{~A}$ sua cultura tornou-se uma oportunidade para crescer na humildade (e causa de humilhação) pois os monges não perdiam ocasião de lhe recordar que, além de ser um estrangeiro, a sua cultura e instrução não tinham, para a perfeição no caminho escolhido, o mesmo valor dos exercícios ascéticos nos quais muitos deles, apesar de academicamente ignorantes, o excediam sobremaneira. ${ }^{14}$ Como todo o monge, também Evágrio trabalhava manualmente para ganhar a sua vida, sendo copista: para além de cópia de livros fazia também composição de novos volumes, escrevendo-os ele mesmo.

No pequeno grupo de monges das Células reunido ao redor de Evágrio partilhavam-se influências filosóficas e teológicas. O pensamento e a influência de Orígenes estava particularmente presente, a ponto do grupo ser considerado por alguns "origenista". Durante a sua vida Evágrio não foi alvo de nenhuma crítica ou condenação doutrinais por parte da Igreja. De facto, o bispo de Alexandria, Teófilo, que haveria de se tornar perseguidor dos monges

\footnotetext{
${ }^{11}$ Amónios (e os seus três irmãos), Palladio, Mélanie, Rufino, João Cassiano são algumas dessas pessoas.

${ }_{12} \mathrm{Ou}$ apenas "o grupo do Bem-aventurado Evágrio", "a comunidade" ou a "fraternidade" de Evágrio. Ibidem, 27.

${ }^{13}$ Ibidem, 26.

${ }^{14}$ Ibidem.
} 
origenistas do deserto de Nítria, ao redor do ano 400, depois da morte de Evágrio, quis antes ordená-lo bispo, honra que ele recusou ${ }^{15}$.

É nas Células que, com cerca de 54 anos Evágrio morre, pouco depois da festa da Epifania no ano 399, segundo Palladio ${ }^{16}$.

\section{A obra de Evágrio}

Os dezesseis anos que passou no deserto permitiram a Evágrio produzir uma obra intensa, densa e vasta, originalmente escrita em grego mas que foi objeto ao longo do tempo, de traduções em várias outras línguas: siríaco, arménio, copta, árabe, etíope, georgiano e sogdiano (dialecto iraniano). Esta variedade de traduções atesta o interesse que despertou e o apreço com que os seus escritos foram recebidos e transmitidos.

De entre a sua obra sobressai um conjunto de três livros que constituem uma trilogia, como o próprio autor explica numa carta a Anatólios, ${ }^{17}$ constituindo uma espécie de compêndio do pensamento do monge pôntico sobre a vida de oração no monaquismo do deserto egípcio. Esses três livros são o Praktikos (ou Tratado Prático), Gnósticos (O gnóstico) e Kephalaia gnóstica (Capitulos gnósticos).

O Tratado Prático expõe a doutrina ascética de Evágrio. Descreve o conjunto de paixões (ou vícios) que ele entende serem originadas a partir do desejo proveniente da sensibilidade corporal e para aí orientadas. Tais paixões são também objecto de estímulo e confusão provocados pelos diversos demónios ${ }^{18}$ que têm, no seu entender, ódio dos homens e tudo fazem para os desanimar e relaxar no caminho da oração. De forma de libertar-se de tais paixões o monge deve buscar desenvolver a virtude e alcançar um primeiro grau na ascensão espiritual fundamental que vai da matéria até Deus: a apátheia ou impassibilidade. $O$ gnóstico contém conselhos úteis para aquele que, tendo atingido já um determinado grau na ascese, próximo da impassibilidade, começa a entrar e a crescer no conhecimento contemplativo. Instrui-o sobre o

${ }^{15}$ Cf. Socrates Scholasticus, Historia Ecclesiastica, VI, PG 67, 688 B.

${ }^{16}$ Antoine Guillaumont acrescenta que na tradição cristã arménia regista-se uma comemoração de Evágrio no dia 11 de Fevereiro. Antoine et Claire Guillaumont in DSp, 1733.

${ }^{17}$ PG 40, 1221c, cit in Ibidem, 1734.

${ }^{18}$ A demonologia de Évagrio Pôntico é desenvolvida, podendo quase parecer que o autor vê demónios a agir sempre, em tudo, através de todos e em todo o lugar. Este facto corresponde contudo à experiência e ensinamento prático transmitidos pela tradição monástica do deserto. Com efeito certos pensamentos humanos são entendidos por Evágrio como "demónios". 
modo como se há-de comportar no seu ensino, as precauções que deve tomar e os defeitos de que se deve guardar.

Os Capitulos Gnósticos constituem a grande obra doutrinal de Evágrio ${ }^{19}$ que, apesar de importante, é de difícil interpretação, não só pela dificuldade em estabelecer o texto original (devido à perda da quase totalidade do texto original grego e a diversos problemas de "correcção doutrinal" ou "expurgação de elementos origenistas" numa das duas traduções síriacas conhecidas) mas, sobretudo, pelo modo deliberadamente obscuro com que o autor transmitia o seu ensino sobre a contemplação de modo a não ser entendidao senão por aqueles que já tinham preparação e, mais ainda, vivência prática adequada para o entenderem a partir das indicações dadas pelo seu texto. ${ }^{20}$

A estes obras convém juntar, em termos de importância para o tema da oração, dois outros textos. Antes de mais o De oratione (tratado sobre Oração), considerado o mais importante de todos os livros do autor sob o ponto de vista doutrinal, especialmente no que respeita à doutrina mística de Evágrio. Em segundo lugar, de entre o espólio de cartas conhecidas, a longa Carta a Melânia, onde se pode encontrar uma síntese da doutrina de Evágrio. ${ }^{21}$ A sua forma de escrever é analítica: parágrafos geralmente curtos (às vezes longos) a que ele chama "capítulos" (kephalaia), que fazem sentido por si mesmos e propiciam uma actividade reflexiva e meditativa em virtude do seu conteúdo e da sua forma por vezes algo esotérica e hermética, propositadamente escolhidos para não desvelarem excessivamente ou indevidamente o que é a ciência contemplativa. ${ }^{22}$

\section{Influências filosóficas e teológicas e a recepção do seu pensamento}

Evágrio apresenta na sua obra um conjunto de influências filosóficas (com destaque para Platão, Estoicismo, Plotino) e teológicas (sobretudo Orígenes, Basílio Magno, Gregório Nazianzeno, Clemente de Alexandria e a

\footnotetext{
${ }^{19}$ A. Guillaumont, Les «Képhalaia Gnostica» d'Évrage le Pontique et l'histoire de l'origénisme chez les Grecs et chez les Syriens (Patristica Sorbonensia 5), Éditions du Seuil, Paris 1962. Daqui em diante a obra será referida como Képhalaia.

${ }^{20}$ Prólogo do Tratado Prático, parágrafo 9. Traité Pratique II, 493.

${ }^{21}$ Uma boa síntese das obras de Evágrio pode ser encontrada em Antoine et Claire GuILlaumonT in DSp 1733-1737. Também se pode encontrar uma interessante lista das obras evagrianas, juntamente com a avaliação da veracidade, em http://evagriusponticus.net

22 "Velámos certas coisas, obscurecemos outras, para 'não dar aos cães aquilo que é santo [...]." (Traité Pratique II, 493-495.)
} 
tradição dos Padres do Deserto - António, Macário, João de Licopolis - com os as suas sentenças ou Apotegmas). Ele incorpora estas influências mais empíricas próprias da tradição monástica num corpo de afirmações doutrinais criado por si, de cariz mais especulativo, estruturado a partir da "tradição filosófica e teológica inteiramente estranhas ao espírito dos solitários egípcios, constituindo assim um sistema vigorosamente pessoal."23

A influência de Orígenes no pensamento de Evágrio e na doutrina presente na sua obra viria a consequências sérias, amplas e duradoiras, na recepção e transmissão dos seus escritos. Com efeito, cerca de 150 anos depois da sua morte, em 553, Evágrio foi condenado, conjuntamente com Orígenes e Dídimo, pelos Padres do V Concílio Ecuménico de Constantinopla. Nas actas desse concílio podemos verificar, segundo A. Guillaumont, que "o origenismo denunciado pelos quinze anátemas antiorigenistas responde ponto por ponto ao de Evágrio, nomeadamente à cristologia que lhe forma o núcleo."24

$\mathrm{O}$ origenismo presente na doutrina evagriana e a condenação conciliar da sua cristologia tiveram, como não poderia deixar de ser, um grande peso na influência que a sua obra exerceu desde então e no modo como ela foi transmitida daí em diante. Muitos dos seus livros em grego foram destruídos e só puderam ser recuperadas através de traduções previamente feitas dos originais para outras línguas, sobretudo para Siríaco e Arménio. Outras vezes as obras foram conservadas em parte mas sofreram uma expurgação de todas as teses ou conteúdos origenistas, de modo a poderem conservar e transmitir um ensino sem qualquer erro doutrinal. Nos casos em que isso aconteceu, tal opção deformou o texto original e impediu o conhecimento do pensamento do autor. ${ }^{25}$

Por outro lado, um dos métodos que se começou a usar para não perder o pensamento de Evágrio depois de condenado, foi o de copiar as suas obras colocando-as sob uma falsa autoria, de modo a evitar que fossem rejeitadas ou destruídas. É o caso do De oratione, cujo nome do autor atribuído é Nil mas, como I. Hausherr provou, através da crítica textual, é de Evágrio. ${ }^{26}$ Assim

\footnotetext{
${ }^{23}$ Antoine et Claire Guillaumont in DSp, 1737.

${ }^{24}$ Cf. A. Guillaumont, "Évagre et les anathématismes antiorigénistes de 553", Communication à la Third International Conference on Patristic Studies, Oxford, 1959, cit in Ibidem, 1741.

${ }^{25}$ Este caso deu-se concretamente em relação à obra Kephalaia gnóstica. Existem duas versões em Siríaco, uma expurgada de origenismo e outra original, sem cortes.

${ }^{26}$ Irenée Hausherr, Les leçons d'un contemplatif : le traité de l'oraison d'Évagre le Pontique, Beauchesne et Ses Fils, Paris 1960. Daqui em diante esta obra será referida com a abreviatura "De oratione".
} 
também se explica que a recepção da sua obra tenha sido heterogénea depois do ano 553: aceite, apreciada e transmitida por uns (sobretudo os Sírios - que conservaram toda a obra do autor ainda que às vezes a expurgassem do origenismo que continha - e os Arménios, mas também algumas figuras do mundo latino, entre eles S. João Cassiano), reprovada e condenada por outros (particularmente S. Jerónimo ${ }^{27}$ ). No entanto e apesar das resistências e da condenação, "a sua influência foi decisiva na formação da doutrina ascética cristã tanto no Ocidente como no Oriente" ${ }^{28}$, influência que, naturalmente, perdura até aos dias de hoje. Um enorme número de figuras significativas na tradição cristã foi influenciado por e transmitiu o pensamento de Evágrio, sobretudo relativamente à oração. Nesse grupo destacam-se, entre outros, João Cassiano ${ }^{29}$, Dionísio Areopagita, Máximo Confessor, João Clímaco, Isaac de Nínive e Simeão, o Novo Teólogo. ${ }^{30}$

\section{A antropologia teológica em que se funda a doutrina espiritual de Evágrio}

Para compreender a doutrina espiritual de Evágrio sobre a oração é fundamental ter uma noção geral sobre a sua antropologia teológica e das influências filosóficas que estruturaram o seu pensamento.

Qual é então a compreensão do ser humano que tem Evágrio? Que leitura faz da sua origem e destino à luz do mistério de Cristo e da Igreja?

\footnotetext{
${ }^{27} \mathrm{~S}$. Jerónimo manifestou grande hostilidade para com os escritos de Evágrio, reprovando sobretudo a sua doutrina da "impassibilidade"ou apatheia. Cf. Antoine et Claire Guillaumont in DSp, 1741.

${ }^{28}$ Ibidem.

29 “Contudo a influência de Evágrio foi grande no mundo latino. Desde logo por João Cassiano, o primeiro que, mesmo se nunca nomeia Evágrio, foi buscar muito dele para a elaboração da sua doutrina ascética: o simbolismo da veste monástica, a teoria dos oito vícios, a teoria da oração. $\mathrm{O}$ origenismo de Evágrio e a condenação de que este foi objecto pesaram fortemente na influência que a sua obra exerceu. Apesar disso esta influência foi considerável. Pode-se dizer que ela foi decisiva na formação da doutrina ascética cristã tanto no Ocidente como no Oriente." (Ibidem.) ${ }^{30}$ Existe um excelente estudo crítico das várias versões da Practiké de Evágrio, feito por Claire Guillaumont, no qual a autora elenca a lista de autores que de forma directa ou indirecta, foram influenciados e transmitiram nos seus escritos o pensamento ascético deste autor ou parte dele. Ver Traité Pratique I, 166-317.
} 


\subsection{Concepção teológica e metafísica do mundo: grandes linhas ${ }^{31}$}

Segundo autor em estudo, no princípio (antes da existência do ser humano tal como o conhecemos na terra) existia uma hénade (que no sistema neoplatónico consiste numa entidade espiritual una, sem realidade corporal/ material) formada pelo conjunto dos seres racionais (logikoi) que são intelectos (nous) puros, criados iguais entre eles para conhecerem Deus, o Inteligível ou a Ciência Essencial por excelência. Foram, portanto, criados para o Verbo ou para a contemplação da Ciência Essencial, para serem unidos a Deus que é, neste pensamento, Unidade ou Mónada onde não existe nem matéria nem multiplicidade.

Devido a uma negligência e relaxamento da actividade contemplativa destes intelectos puros, deu-se uma quebra na hénade primitiva. Tal ruptura constituiu um movimento que teve por consequência não apenas cessar a união dos intelectos com a Unidade que, assim, perderam a ciência essencial dada pela contemplação, mas também quebrar a unidade dos intelectos entre si introduzindo entre eles a diferenciação e a separação. Os intelectos sofrem graus diferentes de decadência ou ruptura na sua união com a Unidade, com a Ciência Essencial, ficando uns com maior ignorância do que outros a respeito da Ciência Essencial ou conhecimento face a Deus.

No entanto, como a Unidade é um Deus misericordioso e providente não os abandona a si mesmos no seu decaimento. Dá-lhes um modo de recuperarem gradualmente a ciência essencial através da criação dos corpos e dos mundos próprios para cada espécie de corpo. Esta é uma segunda criação (ou um segundo momento na criação), distinta dos seres puramente racionais (logikoi). Ela tem por fim dar a cada intelecto decaído um corpo e estabelecê-lo no mundo adequado ao seu grau de queda. Assim são criados os corpos dos anjos, dos homens, dos demónios e os seus respectivos mundos. Todos os corpos são constituidos pelos mesmos elementos materiais mas diferem nas proporções desses elementos.

Evágrio não entende a união do intelecto decaído a um corpo material como um castigo nem considera o corpo mau. Também não o entende como uma prisão para o intelecto. O corpo e o mundo que correspondem a cada intelecto decaído são antes um instrumento ou meio de salvação. ${ }^{32}$ Uma vez

\footnotetext{
${ }^{31}$ Este ponto é desenvolvido em paralelo com o resumo que A. Guillaumont apresenta em Ibidem 1739-1741. Uma exposição mais pormenorizada pode ver-se em Képhalaia, 37-39.

${ }^{32}$ Este aspecto importante separa o pensamento de Evágrio dos origenistas seus contemporâneos. Cf. Ibidem, 110-112.
} 
unidos ao corpo material, os intelectos já não têm participação na ciência essencial mas têm, segundo Evágrio, um outro tipo de ciência: a contemplação ou Gnose, adaptada ao seu estado e grau de queda. Cada qualidade de ser anjo, homem ou demónio - deve alcançar e exercer um determinado modo de contemplação apropriado para a sua salvação: a contemplação espessa ou grosseira (própria dos demónios e dos homens ímpios), a contemplação natural segunda (própria dos homens), a contemplação natural primeira que é própria dos anjos e para além da qual se encontra a ciência da Unidade ou Ciência essencial, reservada aos intelectos completamente purificados.

O intelecto "corporalizado" passa por diversos tipos de contemplação, num processo ascendente e progressivamente libertador da influência da matéria, num itinerário de salvação progressivo e ascensional, em direcção à Ciência essencial que é contemplação de Deus mesmo, visão da Trindade. Cada passagem para um tipo de contemplação diferente e superior dá-se por meio de uma morte-ressurreição. Esta permite a ascensão do intelecto introduzindo-o temporariamente numa outra categoria de corpo e de mundo, cada vez mais espiritual, até que os seres racionais, libertos de toda a matéria e do espaço possam ser unidos de novo à Ciência Essencial ou ter a visão de Deus mesmo.

Podemos perceber quão problemático e polémico este pensamento é para a fé cristã e os motivos pelos quais a doutrina origenista de Evágrio foi mais tarde condenada.

Neste esquema o papel de Cristo como redentor tem também o seu lugar. Contudo a concepção que Evágrio tem de Cristo é complexa e não isenta de aspectos teologicamente polémicos.

Cristo é, desde o início, um intelecto igual a todos os outros criados por Deus e que formavam a hénade primitiva e portanto sem estar unido a um corpo. Distingue o facto de ser o único que permaneceu unido à ciência essencial, sem qualquer decaimento na união com Deus. É a este intelecto racional que não sofreu decaimento algum (o logikós incorrupto) e, por isso mesmo, que existe estado de união íntima com a ciência essencial a que o autor chama Cristo. É a união do intelecto a Deus, e em concreto ao Verbo, que o faz ungido, isto é, Cristo. Contudo o intelecto puro Cristo, mesmo se criado desde sempre em profunda união com o Verbo, não é o Verbo. A união com o Verbo não faz de Cristo, segundo Evágrio, um ser conatural à segunda Pessoa da Trindade, isto é não o faz ser a ciência eterna. Este "Cristo" não é, nesta fase, o Verbo feito carne até porque a corporalidade não existe no início da criação. 
Como escreveu Evágrio, "[...] [o] intelecto é Cristo que está unido à ciência da Unidade." (Képhalaia Gnostica I, 77) ${ }^{33}$.

Através desta citação fica patente que Evágrio usa nos seus escritos a mesma palavra - Cristo - de forma equívoca. Usa-a em sentido próprio e em sentido impróprio. Em sentido próprio e estrito, Cristo é uma criatura, intelecto racional criado, unida ao Verbo de Deus mas sem ser Deus. Em sentido impróprio Evágrio usa por vezes a palavra Cristo aplicando-a ao Verbo de Deus em virtude da união mantida desde sempre por este com o intelecto "crístico". Neste sentido Cristo tem em si sempre o Verbo mesmo se não é o Verbo. Assim escreveu:

Cristo não é conatural da Trindade, uma vez que também não é ciência eterna, mas só ele tem sempre em si, inseparavelmente, a ciência eterna. Mas o Cristo, quero dizer aquele que veio com o Verbo de Deus e em espírito é o Senhor, é inseparável do seu corpo e pela união é conatural ao seu Pai, uma vez que é também ciência eterna (Képhalaia Gnostica V, 14) ${ }^{34}$.

A cristologia de Evágrio não escapa a uma concepção origenista e problemática da união hipostática, da união entre a natureza humana e a natureza divina em Jesus. ${ }^{35}$

Os dois privilégios cristológicos que acabamos de explicitar - um intelecto que sempre existiu unido à ciência essencial e a comunhão que com esse intelecto tem desde sempre o Verbo - são o fundamento para o papel insubstituível que Cristo tem na salvação dos seres racionais (logikoi). É Cristo, intelecto incorrupto ungido pela união íntima com o Verbo, que se empenha na salvação dos intelectos decaídos. É na criatura Cristo, e não em Deus, que se realiza segunda criação: a dos vários corpos e dos seus diferentes mundos, seres segundos nos quais ele introduziu a contemplação que possui, "sabedoria cheia de verdade". "O criador dos seres segundos, o 'demiurgo' [...] é portanto Cristo, e não Deus ele mesmo, o qual é somente o criador dos seres primeiros ou intelectos." 36

\footnotetext{
${ }^{33}$ Cit in Ibidem, 152.

${ }^{34}$ Cit in Ibidem, 153.

35 "A unção inteligível é a ciência espiritual da Unidade santa, e Cristo é aquele que está unido a esta ciência. E se é assim, Cristo não é o Verbo no início, de modo que aquele que foi ungido não é Deus no princípio, mas aquele (logikós) graças a este (Verbo) é o Cristo; e este [Cristo], graças àquele [o Verbo], é Deus." (Képhalaia Gnostica IV, 18). Cit in Ibidem 154.

${ }^{36} \mathrm{Ibidem}, 155$. Como refere A. Guillaumont, a doutrina de Evágrio neste ponto é idêntica à que está exposta e condenada nos quinze anátemas do V Concílio de Constantinopla em 553.
} 
É ainda Cristo (e não o Verbo) que incarna, que cria um corpo humano para si mesmo. Cristo preside ao primeiro julgamento e a todos os julgamentos que hão-de vir dando a cada um, a cada novo julgamento, o mundo e o corpo que lhe convêm. "Não é o Verbo de Deus quem desceu ao Sheol e subiu ao Céu, mas Cristo que tem em si o Verbo." (IV, 80) ${ }^{37}$

No pensamento de Evágrio, Cristo tomou voluntariamente para si um corpo semelhante aos dos logikoí decaídos de modo a poder ajudá-los, revelando-lhes a ciência essencial. Mas o mais importante na união a Cristo não é a união ao seu corpo, ao que nele é participação da matéria corporal mas sim a união ao seu intelecto puro ou noús sempre unido à ciência contemplativa mais alta ou essencial. Por isso Evágrio se esforça no seu ensinamento espiritual por orientar o monge, no seu processo de ascenção contemplativa, no sentido de um despojamento sensível, de forma a que não queira ter de Cristo ou de Deus uma percepção sensível, material, marcada pela multiplicidade ou pela forma, já que o noús e Deus, a quem está unido, não são determinados por nenhuma destas limitações.

Existe também na concepção metafísica de Evágrio uma solidariedade interna aos seres decaídos: os menos decaídos, os anjos, ajudam aqueles que o são num grau superior, os homens.

A escatologia ${ }^{38}$ de Evágrio, na esteira de Orígenes, aceita a teoria da apocatástase, ou restauração final de todos os seres. No fim, depois de uma ascensão de todos os seres decaídos a quem foi dado um corpo, incluindo os demónios, terão passado por meio de um processo ascensional, pelos diversos mundos múltiplos e diversos próprios a cada grau de decaimento, vindo a alcançar gradualmente o estado angélico, caracterizado pela união de um inteleto a um corpo espiritual. Esse momento constitui um primeiro período escatológico, ao qual Evágrio chama metaforicamente o "séptimo dia" 39 , durante o qual o reino de Cristo se estende sobre todos os logikoí. Este reino não é definitivo mas deve dar lugar, por meio de um processo de morte e ressurreição, à fase escatológica seguinte, o "oitavo dia", designação igualmente simbólica. Será então que os logikoí, herdeiros de Cristo, se tornarão seus co-herdeiros, isto é, reencontrarão a igualdade com Ele na participação da ciência essencial.

\footnotetext{
${ }^{37}$ Ibidem.

${ }^{38}$ A complexa escatología de Evágrio Pôntico não pode ser aqui apresentada senão de modo reduzido e necessariamente parcial.

${ }^{39} \mathrm{O}$ "sexto dia" é o período de vida que decorre na condição humana e durante o qual se deve viver segundo o ideal ascético da Practiké.
} 
Todos serão "ungidos" pela sua união à Ciência essencial e tornar-se-ão outros “cristos", sendo co-herdeiros de Cristo $^{40}$. Ocorrerá então a abolição completa do corpo e da matéria que o constitui, com tudo o que isso implica: abolição da multiplicidade, número, modos e nomes, dando a reintegração de todos numa unidade que é Cristo intelecto que permaneceu sempre unido à Unidade. Uma vez que todos ficarão unidos a Cristo e entre si, em igualdade com Ele, todos participarão n'Ele da ciência essencial e da Unidade, podendo por isso ser, de uma certa maneira, chamados Deus tal como Cristo, poder ser chamado tal por ter em si o Verbo. Como escreve A. Guillaumont a partir da sua leitura do original siríaco, "esta identificação a Cristo é prometida a todos os intelectos sem excepção."41

No oitavo dia o reino de Cristo chegará ao fim e Cristo submeter-se-á a Ele próprio ao Pai.

Um olhar atento sobre esta doutrina reconhece nesta síntese a presença de várias teses de influência platónica e neoplatónica, de onde se destacam uma certa visão dualista (intelecto ou noús - corpo), a preexistência do intelecto (noús) em relação ao corpo e a sua migração através de um processo ascensional, contemplativo ou gnóstico ${ }^{42}$, que corresponde a uma aquisição e prática da virtude, para sair do mundo das formas, aparências ou multiplicidade até chegar ao mundo do Uno ou da Unidade. Igualmente encontra dificuldades e erros na compreensão doutrinal que Evágrio tem da condição cristológica, da união hipostática entre natureza humana - Verbo bem como do acto criador pelo qual a corporalidade vem à existência.

\subsection{Noção de homem em Evágrio}

Dentro do grande quadro metafísico e escatológico origenista e platónico/ plotiniano em que se move Evágrio, podemos agora compreender com pormenor a sua ideia de homem. Esta é fundamental para percebermos o seu itinerário espiritual, as suas fases, o modo de ascender de umas a outras, a dificuldade, tentações e graças que irá encontrar e os remédios a utilizar ou as

40 "O co-herdeiro de Cristo é aquele que chega à Unidade e se deleita da contemplação com Cristo." (Képhalaia Gnostica IV, 8.) Cit in Ibidem.

${ }^{41}$ Ibidem, 156.

${ }^{42}$ Nesse sentido a escatologia e o processo ascensional de Evágrio implicam uma certa concepção de reincarnação, já que os logikoí vão passando de mundo para mundo e adquirindo corporalidades diferentes e próprias de cada mundo até à completa libertação da corporalidade no "oitavo dia”. Cf. A. Guillaumont, Képhalaia, 249-252. 
virtudes a desenvolver. Tudo isto dentro de um contexto muito específico que é o da vida semi-anacorética (ou semi-eremítica) dos monges do deserto das Células vivida, na tradição monástica do deserto, a partir da noção de hesyquía (quietude, silêncio e recolhimento orantes). Os monges viviam praticamente sós, encontrando-se apenas uma vez por semana, no sábado à noite, para tomarem uma refeição juntos (a agapé) e celebrarem a liturgia do Domingo. ${ }^{43}$

Vimos que Evágrio considerava o início da condição humana no intelecto incorpóreo, centro da vida espiritual e criado para participar da Ciência Essencial e estar em união com o próprio Deus o qual, por causa da sua negligência na contemplação, sofreu uma ruptura desta participação com efeitos degradantes e que o colocaram num grau decaído de contemplação. Este intelecto foi posteriormente unido a um corpo sensível e material como ajuda para a sua salvação, corpo sujeito a paixões e impulsos vários, nem todos necessariamente maus, que são governados através da psyché. A psiqué cuja tradução literal seria "alma", não tem em Evágrio o sentido que hoje damos a esta palavra, pois não é o princípio divino, eterno e chamado a participar plena e unitivamente com Deus ${ }^{44}$. É antes um princípio de vitalidade ou princípio anímico do corpo e, por isso mesmo, da ordem da segunda criação. Talvez a palavra "psique" possa ser uma boa tradução enquanto termo que expressa todo o conjunto de energias internas, profundas, racionais e irracionais que se encontra na fronteira aberta entre o que é objectivamente somático e o que não o é, entrando numa zona de maior profundidade, uma profundidade de consciência do "eu", consciência da identidade não desvinculada do corpo.

Evágrio segue a concepção platónica que advoga a existência de uma tríplice partição da alma no ser humano: a parte racional (lógos), a parte irascível (thumos) e a parte concupiscível (epithumía). ${ }^{45}$ As últimas duas, como veremos, que são as responsáveis pela existência de uma dimensão dita "passional" (pathos) que interfere, para orientar ou desorientar, o processo de ascensão ou contemplação para a união com Deus em Cristo que é liderado pela dimensão racional ou noética. Só o intelecto puro (noús), criado incorpóreo, purificado de todas as influências negativas da alma irascível e concupiscível, será elevado à contemplação da Ciência Essencial e luminosa da qual, de certa maneira, participava por criação. O intelecto não é apenas

\footnotetext{
${ }^{43}$ Cf. A. Guillaumont, "Étude historique et doctrinale", in Traité Pratique I, 25.

${ }^{44}$ É o noús se apresenta com essas característas criação directa por Deus, imortalidade e com vocação à união plena com Deus através da união com o Verbo.

${ }^{45}$ Cf. Ibidem, 104.
} 
uma faculdade da alma. Ele é para Evágrio a essência mesma do homem, a sua identidade profunda ou, se quisermos, o seu "espírito" enquanto o corpo (soma) e a alma (psyché) são apenas elementos resultantes da queda ainda que possam ter, em determinado sentido, um papel de ajuda. Mas no grau máximo da contemplação ou união a Deus terão de ser abandonados como dimensões imperfeitas. ${ }^{46} \mathrm{O}$ noús nunca desaparece. O estado do puro intelecto contemplativo é considerado pelo monge pôntico como o estado da oração pura que é, por sua vez, o estado do verdadeiro teólogo ou gnóstico. Este conhece participando na contemplação sábia e luminosa que é Deus mesmo.

Por comparação com o noús a parte irascível e a parte concupiscível são no homem de ordem acidental (segunda criação) e tendem à junção do intelecto decaído com um corpo. Constituem aquilo a que Evágrio chama "a parte apaixonada [pathetikón méros $\left.{ }^{47}\right]$ da alma." ${ }^{48}$

\section{Doutrina ou itinerário espiritual de Evágrio}

O itinerário espiritual de Evágrio divide-se em duas grandes fases a que ele chamou Practiké (Prática) e Gnostiké (Gnostika ou Conhecimento místico). A Prática é a fase predominantemente ascética e a Gnostika é o conhecimento místico que resulta da entrada na fase contemplativa, fruto da graça de Deus e da Sua acção iluminadora e purificadora no intelecto que assim vai sendo elevado e conduzido a um conhecimento místico cada vez mais divino, simultaneamente mais alto, mais profundo e mais luminoso. A gnose tem uma eficácia transformadora e divinizadora do homem, tornando-o cada vez mais capaz de se unir com Deus mesmo e ser assim, "Deus por participação ou graça"49. A gnose subdivide-se em duas etapas ou fases: a physiké (contemplação natural das realidades criadas ou física) e a theologia (ou ciência de Deus). A theologia é o verdadeiro conhecimento místico e espiritual mais alto, perfeito e divino. Assim, num certo sentido, o esquema evagriano passa de duplo a triplo: inicia-se pela prática que é ascética ou purgativa; uma segunda fase que resulta de uma iluminação inicial ou contemplação natural das coisas criadas que é a física e, finalmente, uma terceira fase, a da teologia, que é o

\footnotetext{
${ }^{46}$ Cf. De oratione, $73 \mathrm{~s}$.

${ }^{47}$ Emotiva, tumultuosa, intempestiva, por sentiments de grande alegria ou de grande sofrimento que perturbam o equilíbrio com a dimensão racional da alma.

${ }^{48}$ Traité Pratique II, chap. 78, 667.

${ }^{49}$ É a noção de theósis ou divinização do homem presente na doutrina dos Padres do Deserto.
} 
mais alto estado da contemplação ou ciência mística, fase unitiva em que se dá a divinização do intelecto, totalmente purificado, por acção da graça.

\subsection{A Prática ou ascética}

A prática é "o método espiritual que tem por fim purificar a parte apaixonada da alma." ${ }^{50}$ No ambiente da anacorese monástica de Evágrio este método é proposto como caminho àqueles que, tendo já renunciado ao mundo e aos seus apelos, estando já estabelecidos na hesiquía (ou hesychía), querem agora progredir na sua transformação espiritual. Pressupõe por isso a opção por um determinado estado de vida, de abnegação, aquietamento, simplificação e busca do silêncio interior como via para a união com Deus.

A prática é entendida sobretudo como o grande esforço ou combate que o hesicasta deve travar contra as paixões no homem (e contra os demónios que as despertam) como meio para chegar à apátheia ou impassibilidade, condição fundamental para poder progredir e entrar na gnose ou da contemplação. As paixões que é preciso ordenar ou vencer são atracções e pulsões que envolvem e movem a parte somática e sensitiva mas também o mundo das energias internas psíquicas, responsáveis pelos comportamentos e o carácter. Esta fase requer o empenho, a determinação diligente (lembremos que foi por negligência da actividade contemplativa que os logikoi caíram numa existência degradada e num certo grau de separação de Deus) do orante para resistir às muitas tentações que lhe virão dos demónios, interna e externamente, para o desviarem do ideal.

A prática consiste no exercício das virtudes cristãs e na rejeição dos vícios. É pela perseverança e vitória nesta luta (afectiva, psíquica e espiritual) que se entra no estado de impassibilidade. O processo é posto em movimento por um conjunto de virtudes: a fé é o começo da caridade e o fim da caridade é a ciência de Deus. Tudo isto é conduzido dentro do temor de Deus que leva à perseverança e na abstinência que geram no homem a esperança e esta boa esperança glorificá-lo-á. ${ }^{51}$ A prática é representada e dinamizada por estas cinco virtudes fundamentais: fé, temor de Deus, abstinência, perseverança e esperança. Evágrio assume uma longa tradição que considera que as virtudes se geram umas às outras pela sua prática.

\footnotetext{
${ }^{50}$ Traité Pratique II, chap 78, 667.

${ }^{51}$ Cf. Sentenças aos Monjes, 3-5. Cit in: A. Guillaumont, "Étude historique et doctrinale", in Traité Pratique I, 53.
} 
A luta que se trava ao longo do processo que vai da hesiquía à apátheia ou impassibilidade é o território da Prática. É uma luta, sobretudo, contra os pensamentos (logismoi) porque "com os seculares os demónios lutam utilizando de preferência os objectos. Mas com os monges é mais frequentemente através da utilização dos pensamentos; os objectos, com efeito, faltam-lhes por causa da solidão." ${ }^{52}$ Estes objectos são coisas e pessoas e os pensamentos são tentações que incitam a vícios e nos atraem para o que é material e sensível, múltiplo e variado. Evágrio afirma que contra os anacoretas, à falta de mediações outras, os demónios combatem nus. ${ }^{53}$

É através de sugestões internas vindas pelo pensamento ou pelas sensações que os demónios combatem. A cada vício, a cada pensamento ou logismós corresponde um daimôn ou um pneuma especializado. ${ }^{54}$ Constrói assim a sua teoria dos oito pensamentos (que são oito tentações), a partir de influências estoicas, que está na base do que hoje é na tradição cristã a lista dos pecados capitais. Esses oitos vícios ou pensamentos são: o pensamento da gula (cap. 7), da fornicação (cap. 8), da avareza (9), da tristeza, da cólera, da acédia, o pensamento da vaidade ou vã glória e, finalmente, o pior de todos, o pensamento ou demónio do orgulho. Ao longo dos capítulos 15-33 do Tratado Prático, Evágrio expõe a pedagogia dos ataques e os remédios a empregar ${ }^{55}$.

Um vício ou demónio particularmente relevante em Evágrio é a acédia, palavra cuja tradução é muito difícil pela complexidade do significado que o autor lhe dá. Este demónio não ataca apenas uma ou outra parte da alma mas a alma toda, no seu conjunto, por todas as partes abafando mesmo o intelecto ${ }^{56}$. A ordem dos vícios não é arbitrária.

Não há uma explicação formal dada pelo autor mas há razões para crer que, tal como acontece com as virtudes, os vícios conduzem uns aos outros segundo uma relação interna. Não nos deteremos na demonologia de Evágrio nem na análise dos vícios e dos seus remédios apesar do seu interesse porque saiem do âmbito deste estudo. Iremos antes deter-nos na importante noção de impassibilidade ou apatheia: nos sinais que a pré-anunciam e na virtude da caridade à qual conduz.

\footnotetext{
${ }^{52}$ Traité Pratique II, capítulo 48, 609.

${ }^{53}$ Cf. Traité Pratique II, capítulo 36, 583.

${ }^{54} \mathrm{Na}$ esteira da tradição judaica e de Orígenes, Evágrio usa no Prático, como equivalentes, o termos daímon, logismós ou pneuma. Cf. Traité Pratique I, 60.

${ }^{55}$ Em parte estas indicções estão também na sua obra Antirrhético e no tratado Sobre Oração (De Oratione).

${ }^{56}$ Cf. A. Guillaumont, "Étude historique et doctrinale", in Traité Pratique I, 88s.
} 
A noção de impassibilidade é central na sua doutrina ascética ${ }^{57}$ de Evágrio e foi por vezes mal compreendida, por exemplo por S. Jerónimo. A impassibilidade é o estado que se relaciona com a virtude da enkrateia (temperança) e que abre ou dá passagem para a virtude e vivência do agapé (amor, caridade). É com a caridade que o monge entra na fase da contemplação ou gnose. A impassibilidade é o amor ordenado que leva à contemplação e purifica ${ }^{58}$. A caridade é o freio da parte irrascível. ${ }^{59}$ "A impassibilidade tem por filha a caridade" e esta "leva à ciência" ${ }^{60} \mathrm{~A}$ impassibilidade é o caminho que leva, pelo domínio de si, à entrada na experiência de ser-se movido pelo amor de Deus e não pelos vícios. A impassibilidade não é, portanto, uma insensibilidade geral a respeito de tudo ou apenas daquilo que seja somático ou psíquico. É um estado de tranquilidade, de domínio e de ordenação de si. Inácio de Loyola dirá no sec. XVI que é necessário "fazermo-nos indiferentes a todas as coisas criadas" 61 para vivermos totalmente para Deus, cumprindo a Sua vontade e buscando em tudo escolhar apenas o que mais nos conduz para o fim para que fomos criados, isto é, o amor e serviço de Deus. ${ }^{62}$

É na parte irascível e concupiscível da alma que se encontram as paixões (ou a fraqueza face a elas) que é preciso curar ou purificar pela ascese. $\mathrm{O}$ intelecto fica assim liberto das suas influências negativas e pode entregar-se com novo vigor à actividade da contemplação ou oração ou conhecimento da ciência essencial de modo "puro". Uma vez purificadas, curadas e ordenadas, parte irascível e parte concupiscível da alma tornam-se então, agindo segundo a sua natureza, uma ajuda para o processo contemplativo e não um impedi-

${ }^{57}$ Não foi ele o primeiro ou o único a usar esse termo no contexto da espiritualidade cristã. Já Clemente de Alexandria o tinha usado no sec. II, propondo-o como o ideal do asceta cristão e considerando Cristo o ánthropos apathicos ao dizer que a sua alma é sem paixões (A/) paq $\backslash \backslash \backslash \backslash \backslash \backslash \backslash \backslash h \backslash j$ th $\backslash n$ yuxh)))). Cf. Clément d’Alexandrie, Le Pédagoge, I (H-I. Marrou - M. Harl), Sources Chrétiennes 70, Cerf, Paris, 1960, chap 4, 1.

${ }^{58}$ Traité Pratique II, chap 38, 587.

${ }^{59}$ Cf. Ibidem.

${ }^{60}$ Prólogue $\$ 8$, in Traité Pratique II, 493.

${ }^{61}$ Exercícios Espirituais 23.

${ }^{62}$ Comentando a noção de "indiferença" em Santo Inácio de Loyola, S. Arzubialde escreve: "La Indiferencia es el resultado de la experiencia espiritual, de Dios-Amor, sobrecogedor y Padre. No se trata de la fría ataraxia por la que el hombre hubiera aniquilado sus afectos y ya todo le diera igual. La Indiferencia está, por su misma naturaleza, cargada de afecto. Es la docilidad de la fe que habla la Escritura. Corresponde a la experiencia espiritual de quien ha sentido que Dios le ama, y la imagen de Dios como Padre Y seguridad absoluta a cuyas manos el hombre se abandona [...]." (S. Arzubialde, Ejercicios Espirituales de S. Ignacio, Mensajero y Sal Terrae, Santander 1991, 77.) 
mento: "a parte concupiscível desejando a virtude e o prazer que acompanha a ciência espiritual, a parte irrascível lutando para a salvaguarda dos seus bens e para proteger o intelecto contra os demónios que procuram roubá-la." ${ }^{63}$

Assim a noção da impassibilidade em Evágrio não implica a desaparição (pelo menos até ao "oitavo dia") da irascibilidade (thumós) nem da concupiscência (epithumía) ${ }^{64}$ e essa sua concepção difere profundamente da que tinham a respeito da mesma noção Clemente de Alexandria e Fílon. ${ }^{65}$ Elas podem, uma vez ordenadas e purificadas, ajudar o intelecto no seu itinerário contemplativo, defendendo e atraindo em direcção a Deus. O corpo é um auxiliar adequado ao intelecto e não um estorvo, pelo que Evágrio critica tanto os que se suicidam (cap 52) como os que fazem uma ascese excessiva que destrói e prejudica o corpo (52). O importante é a moderação e a regularidade (91), um "regime sempre igual" (29). Uma vez eliminadas as paixões a anacorese torna-se doce (36).

Contudo, a impassibilidade acabará quando o intelecto for, finalmente desprendido do corpo ainda que espiritual. Deus não tem qualquer materialidade a que esteja unido e por isso a impassibilidade do asceta fá-lo não igual a Deus mas aos anjos. ${ }^{66}$

De entre os vários sinais pelos quais o monge pode perceber que se está a aproximar do portal da impassibilidade, Evágrio refere entre outros: "não experimentar nenhuma paixão diante dos objectos" e mesmo "permanecer imperturbável diante da sua recordação" (c. 67); a mestria em "caçar uns pensamentos demoníacos através de outros" (58) e, sobretudo, não ser assaltado de noite, pelas forças do inconsciente (leitura psicanalítica actual), por sonhos que brotam da profundidade da sua alma. Todas as dimensões estão em paz e ordem. Outros sinais: o monge começa a conseguir rezar sem distrações (63), não imagina já coisa alguma do mundo na oração (65) e, sobretudo, o sinal que lhe é dado quanto começa a ter a visão do seu próprio intelecto como luz e percebe a sua própria luz interior (64).

\footnotetext{
${ }^{63}$ A. Guillaumont, "Étude historique et doctrinale", Traité Pratique I, 105. Cf. Traité Pratique II, chap 24 e 86 .

${ }^{64}$ No evangelho de Lucas o autor afirma que Jesus desejou com "epithumia” (desejo apaixonado) celebrar aquela páscoa com os seus amigos. Cf. Lc 22, 15.

${ }^{65}$ Cf. A. Guillaumont, "Étude historique et doctrinale”, in Traité Pratique I, 106.

${ }^{66}$ Cf. Traité Pratique II, cap 87, 679.: "Aquele que progride na prática diminui as suas paixões, aquele que progride na contemplação diminui a sua ignorância. Ora, das paixões, haverá um dia destruição completa, mas no que concerne à ignorância, há uma, diz-se, que tem um fim, e outra que não o tem."
} 
Está assim no portal da gnose, da contemplação ou da física como ciência dos seres naturais.

\subsection{A gnose ou contemplação (theoría) mística}

A gnose, vimo-lo, desdobra-se em duas outras fases ou graus: a física (ou contemplação natural) e a teologia (ou ciência de Deus). A contemplação natural também se subdivide: em contemplação natural segunda (que tem por objecto as naturezas segundas isto é os corpos, a matéria) e a contemplação natural primeira (que contempla as naturezas primeiras ou espirituais). Trata-se de um conhecimento que leva o orante a passar de um conhecimento com origem na sensibilidade para outro mais interior e sucessivamente mais intuitivo, espiritual e desligado da mediação da matéria e da forma. É o lógos, a inteligibilidade interna da realidade, a sua dimensão espiritual-intelectual e oculta que esta contemplação se propõe conhecer, para assim poder conhecer a sabedoria cheia de verdade que o Criador colocou nelas. É a sabedoria do Criador que, afinal, é o objecto da contemplação natural. A contemplação natural primeira é concebida por Evágrio como participação do conhecimento angélico. Aliás, o tornar-se semelhante a um anjo era o ideial do ascetismo dos Padres do Deserto. Tal fim alcança-se na experiência da visão do intelecto (ou luz da Santa Trindade) a partir de si mesmo, a qual introduz já na theologia, a ciência mística.

"É uma prova de impassibilidade que o intelecto tenha começado a ver a sua própria luz, que permaneça calmo diante das visões do sonho e que olhe os objectos com serenidade." 67

\section{A teologia como oração ou contemplação pura: grau máximo da mística}

$\mathrm{Na}$ terceira fase do processo ascensional ou contemplativo, a teologia, Evágrio descreve e desenvolve uma outra possibilidade ou nível de oração, noção muito própria sua, a que chama "oração pura". João Cassiano, transmissor do pensamento de Evágrio Pôntico para o mundo latino, também a referirá nos seus escritos sobre oração. Esta contemplação é, na prática, o nível mais excelso e místico, ainda mais elevado que a contemplação das natu-

${ }^{67}$ Traité Pratique II, chap 64, 649. 
rezas espirituais ou primeiras. A oração pura é a verdadeira theologia enquanto contemplação de "Deus Trino" ou "do lugar de Deus".

Nesta contemplação o orante tem de se desprender de toda a percepção de forma, de multiplicidade, de conteúdo ou noção de espaço para entrar numa simplicidade una, através de um desejo ignorante (póthos ápeiros ${ }^{68}$ ), na medida em que não tem nenhuma percepção ou conhecimento prévio do que busca ou deseja. Por isso diz: "mesmo se a inteligência se eleva sobre a contemplação da natureza corporal, ela não tem ainda a vista perfeita do lugar de Deus, pois pode estar na ciência dos inteligíveis e partilhar da sua multiplicidade. ${ }^{\circ 9}$

Por contraste com as formas anteriores de contemplação, a entrada nesta experiência de oração "pura" não resulta de esforço de aquisição ou de uma inquietação mas é marcada pela paz e pelo repouso contemplativo, como dom e não como busca. ${ }^{70}$ É um conhecimento essencial de Deus ${ }^{71}$ É uma ciência que não se ensina e não se aprende: é dada e recebe-se. ${ }^{72}$

A pureza desta oração está vinculada ao carácter de total despojamento ou nudez do intelecto, dito puro, porque não agarrado ou condicionado por nenhuma realidade criada. "O intelecto nu pode dizer qual é a sua natureza"73; "o espírito nu é aquele que se aperfeiçoou na sua própria vista e que foi julgado digno de participar na contemplação da Santa Trindade ${ }^{74}$." "75 "Quando o noús for despojado do homem velho e tiver revestido o homem da graça, então ele verá o seu próprio estado no tempo da oração, semelhante à safira e à cor do céu." "76 Como afirma A. Guillaumont. "Ver em si o lugar de Deus não é possível senão quando Deus habita em nós." 77 A oração pura, em espírito "nú", é acção de Deus no homem.

"Não desejes ver sensivelmente os Anjos, nem as Potências, nem Cristo, para não perderes completamente o bom senso, acolhendo o lobo em lugar do

${ }^{68} \mathrm{Po} / \mathrm{qoj}$ a)/peiroj. De oratione, 154.

${ }^{69}$ De oratione, chap 57, 80.

${ }^{70}$ Cf. Guillaumont, (Ed.), Les six Centuries des 'Kephalaia gnostica' (Évagre le Pontique), Patrologia Orientalis 134, Brepols, Turnhoult 1985, 5, 65. Daqui em diante a obra será referida por Centuries.

${ }^{71}$ Cf. Centuries 3, 12.

${ }^{72}$ Cf. Ibidem 4, 53; 5, 81.

${ }^{73}$ Ibidem 3, 70.

${ }^{74} \mathrm{Ou}$ "contemplação da Mónada".

${ }^{75}$ Centuries 3, 6.

${ }^{76}$ Traité Pratique I, 70.

${ }^{77}$ I. Hausherr, «Contemplation. Évagre le Pontique.”, DSp, Tome II-2ème, 1953, 1781. 
pastor e adorando os demónios inimigos."78 "Não terás oração pura se estás embaraçado de coisas materiais e agitado por preocupações contínuas; porque a oração é supressão dos pensamentos." ${ }^{\prime 79}$

Mas esta visão de Deus não é a visão directa ou "beatífica" coisa que neste mundo é impossível: "aspirando a ver a face do Pai que está nos céus, não procures por nada deste mundo perceber uma forma ou uma figura no tempo da oração." "Es "Este aviso, diz, está em perfeito acordo com toda a sua doutrina [...] Deus é inapreensível em si mesmo." ${ }^{11}$

Algo deste despojamento das formas, figuras, pensamentos, da sensibilidade é dado a experimentar através da forma de oração que é a meditação cristã e que é praticada pela Comunidade Mundial de Meditação Cristã fundada pelo monge beneditino inglês John Main. ${ }^{82}$ A meditação cristã é, segundo John Main, também uma forma de oração em que o orante chega a consciência do seu centro, dessa presença na interioridade profunda onde está Deus como presença de Amor-Luz, ao mesmo tempo que o orante se desprende da auto-análise, de querer compreender ou pensar Deus.

À luz da noção evagriana de "practiké" e de "theologia" ganham sentido e aplicabilidade para o nosso tempo, duas afirmações presentes no De oratione que podem ser guardadas e seguidas como lemas de vida, desde que bem compreendidas, também para os cristãos do século XXI que buscam a união com Deus já não nos desertos do Médio Oriente mas nas agitadas cidades o mundo ocidental:

Como o pão é alimento para o corpo, assim a virtude é-o para a alma e a oração espiritual para o intelecto [noús]. (De oratione, cap. 101).

Se tu és um teólogo, oras verdadeiramente; e se tu oras verdadeiramente, és um teólogo. (De oratione, cap. 60).

Esta theologia jamais se extinguirá.

\footnotetext{
${ }^{78}$ De oratione chap $115,147$.

${ }^{79}$ Ibidem, chap $114,144$.

${ }^{80}$ Ibidem.

${ }^{81}$ I. HAUSHERR, “Contemplation”, DSp, Tome I, 1937, 1781s.

${ }^{82}$ Nome original: The World Community for Christian Meditation. Ver http:// www.wccm.org
} 


\section{Conclusão}

O percurso biográfico e intelectual de Evágrio Pôntico (345-399) está enquadrado por uma sólida formação intelectual, onde se destacam as influncias de Gregório de Nazianzo e de Orígenes, recebida em Constantinopla, entre os anos 379-381. Em seguida o seu percurso pessoal levou-o primeiro a Jerusalém antes de se fixar, em 383, no deserto egípcio das Células onde desenvolveu e transmitiu a sua doutrina ascético-mística como caminho da união com Deus.

A sua obra é profunda e tem intuições originais, mesmo se apresenta elementos de clara influência oreginista recebidos com pouca flexibilidade ou recomposição. Originalmente escrita em Grego, a obra evagriana foi tradução em várias línguas orientais (Arménio, Siríaco, Copta, Árabe, Georgianao, Etíope,) graças às quais é possível hoje recuperar escritos cujos originais desapareceram. Para esse desaparecimento contribuiu em parte a condenação de teses origenistas, pelo II Concílio de Niceia (553), que Evágrio incorporou na sua doutrina. Depois deste acontecimento algumas obras de Evágrio Pôntico foram alvo de um processo de expurgação das ideias origenistas aí contidas pelos copistas que replicaram os originais, retirando-lhe as afirmações ou doutrinas condenadas. Já depois da condenação doutrinal, mesmo a cópia das obras originais do autor foi algumas vezes apresentada sob uma falsa autoria, para assim o texto poder aceite por eventuais leitores sem ser objecto de uma condenação ou desconfiança inicial. Em virtude deste expediente motivado pela condenação doutrinal, a recepção da obra do autor foi heterogénea e nem sempre claramente indentificada com o seu autor e por vezes é disputada como sendo da sua autoria obras que não trazem o seu nome. É o caso do Tratado sobre a Oração.

Para o estudo da Teologia Mística do autor são importantes sobretudo três obras: Praktikos(ou Tratado Prático), Gnósticos (O gnóstico) e Kephalaia gnóstica (Capítulos gnósticos). O itinerário espiritual de Evágrio divide-se em duas grandes fases a que ele chamou Practiké (Prática) e Gnostiké (Conhecimento místico). Por seu lado a Gnostiké subdivide-se ainda em a physiké (contemplação natural das realidades criadas ou física) e a theologia (ou ciência de Deus), o conduz a um esquema tripartido de itinerário espiritual.

A Prática é a fase predominantemente ascética. Na fase final deste esforço sobretudo ascético deve ser alcançada pelo orante a virtude da apátheia ou impassibilidade, condição fundamental para o hesicasta poder 
progredir e entrar na gnose ou da contemplação. As paixões que é preciso ordenar ou vencer são atracções e pulsões que envolvem e movem a parte somática e sensitiva mas também o mundo das energias internas psíquicas, responsáveis pelos comportamentos e o carácter. A noção de impassibilidade é central na sua doutrina ascética de Evágrio e foi por vezes mal compreendida, por exemplo por S. Jerónimo. A apátheia, em Evágrio, é o estado que se relaciona com a virtude da enkrateia (temperança), de amor ordenado, que leva à contemplação e purifica e que abre ou dá passagem para a virtude e vivência do agapé (amor, caridade). A impassibilidade não é, portanto, uma insensibilidade geral a respeito de tudo ou apenas daquilo que seja somático ou psíquico. Ela não implica a desaparição da irascibilidade (thumós) nem da concupiscência (epithumía) mas a sua ordenação e equilíbrio. É um estado de tranquilidade, de domínio e de ordenação de si e ordem à maior capacidade receptiva e performativa do amor divino. A compreensão da apátheia em Evágrio Pôntico distingue-se da Clemente de Alexandria e apresenta uma riqueza e um equilíbrio que será interessante aprofundar.

A Gnostika é o conhecimento místico que resulta da entrada na fase contemplativa, fruto da graça de Deus e da Sua acção iluminadora e purificadora no intelecto que assim vai sendo elevado e conduzido a um conhecimento místico cada vez mais divino, simultaneamente mais alto, mais profundo e mais luminoso. Dentro da primera fase do Contemplação natural que é a physiqué, Evágrio admite subfases: a physiqué das substancias segundas (ou realidades materiais, corpóreas) e a das substâncias primeiras (ou naturezas espirituais). A theologia, a etapa mais elevada e sublime, é fase da verdadeira ciência mística e espiritual mais alta, perfeita e divina. É nesta fase que ocorre a união com Deus e começa a ser possível ao orante "que o seu intelecto (noús) comece a ver a sua própria luz" (Traité Pratique II, cap 64) pois Deus, presente nele, faz-se translúcido ao olhar contemplativo. Esta contemplação ou visão de Deus em si introduz na experiência da oração "pura" ou "nua", em que o adjectivo "nú" diz apenas o grau de pureza e despojamento de tudo o que no homem não é Deus e lhe permite, assim, participar interiormente dessa presença de Deus em si. "O espírito nu é aquele que se aperfeiçoou na sua própria vista e que foi julgado digno de participar na contemplação da Santa Trindade. ${ }^{83}$ Nesta fase do itinerante o orante é, verdadeiramente, um theologo porque ora verdadeira e puramente.

${ }^{83}$ Centuries 3, 6. 


\section{Referências Bibliográficas}

ARZUBIALDE, S., Ejercicios Espirituales de S. Ignacio, Mensajero y Sal Terrae, Santander 1991.

BUTLER, C. The Lausiac History of Palladius, t.2, coll. Texts and Studies, Cambridge 1904.

CLÉMENT D'AlEXANDRIE, Le Pédagoge, I (H-I. Marrou - M. Harl), Sources Chrétiennes 70, Cerf, Paris, 1960.

ÉVAGRE LE PONTIQUE, Kephalaia Gnostica, critical edition of Syriac $\mathrm{S}^{1}$ and $\mathrm{S}^{2}$ texts ed. and trans. by A. Guillaumont, (Ed.), Les six Centuries des 'Kephalaia gnostica' (Évagre le Pontique), Patrologia Orientalis 134, Brepols, Turnhoult 1985. Reimpressão: Patrologia Orientalis 134, Brepols, Turnhoult 1985.

_-, Traité Pratique ou Le Moine, Tome I (Sources Chrétiennes 170), Cerf, Paris 1971.

__, Traité Pratique ou Le Moine, Tome II, (Sources Chrétiennes 171), Cerf, Paris 1971.

_- Le gnostique ou A celui qui est devenu digne de la science, (Sources chrétiennes 356), Cerf, Paris 1989.

GARCÍA CORDERO, M. ET Al., Historia de la espiritualidad, Vol.I, Juan Flors, Barcelona 1969.

GUILlAUMONT, A. et C., "Évagre le Pontique", Dictionnaire de Spiritualité Ascétique et Mystique, Tome IV-1 ${ }^{\text {ère }}$, Beauschesne, Paris 1960, 1732.

GUILLAUMONT, A., "Étude historique et doctrinale", in ÉVAGRE LE PONTIQUE, Traité Pratique ou Le Moine, Tome I (Sources Chrétiennes 170), Cerf, Paris 1971.

__, "Évagre et les anathématismes antiorigénistes de 553", in F.L. CROSS (Ed.), Studia Patristica: Papers presented to the Third International Conference on Patristic Studies held at Christ Church, Oxford 1959, Vol. III, Akademie-Verlag, Berlin 1961, 219-226.

_- Les «Képhalaia Gnostica» d'Évrage le Pontique et l'histoire de l'origénisme chez les Grecs et chez les Syriens (Patristica Sorbonensia 5), Éditions du 
Seuil, Paris 1962. HAUSHERR, I., «Contemplation. Évagre le Pontique", Dictionnaire de Spiritualité Ascétique et Mystique, Tome II-2ème, Paris 1953.

__, Les leçons d'un contemplatif: le traité de l'oraison d'Évagre le Pontique, Beauchesne et Ses Fils, Paris 1960.

MIGNE, J.-P. (Ed.), Patrologiae Cursus Completus, Series Graeca, Brepols, Turnhoult 1970.

Teresa Messias

Doutora em Teologia Espiritual pela Pontifícia Universidad de Comillas - Madrid Professora de Teologia na Universidade Católica de Lisboa E-mail: teresamessias@gmail.com

Recebido em 04/04/2013

Aprovado em 13/06/2013 